\title{
RESIGNATION OF A SHAREHOLDER OF A SIMPLE JOINT-STOCK COMPANY
}

\section{Introduction}

The amendment to the Polish Commercial Companies Code (hereinafter: K.s.h.) to enter into force on 1 July 2021 that will introduce a simple joint-stock company ${ }^{1}$ into Polish legal order contains a number of solutions previously unknown to Polish law. One of these is the action for the resignation of a shareholder. The regulation of this institution included in art. $300^{50}$ of the K.s.h. slightly recalls "reversed" action to exclude a shareholder of a limited liability company, and it may cause substantial difficulties in the practice of its application. The purpose of the present article is the dogmatic analysis of art. $300^{50}$ of K.s.h., assessment of the effectiveness of this regulation, and an attempt to optimize it.

\section{Axiology of the art. $300^{50}$ of K.s.h.}

Membership in a company stems from the acquisition of membership rights (shares). This means that it is established and terminated only "through" share-related rights, in such a way that whoever acquires at least one membership right becomes a member of the company, and

* Dr., The John Paul II Catholic University of Lublin; e-mail: pawel.zdanikowski@kul.pl, https://orcid.org/0000-0002-2383-5401.

1 Act of 19 July 2019 amending the act - the Code of Commercial Companies and some other acts, Journal of Laws, item 1655. 
whoever disposes of all its shares ceases to be its shareholder. ${ }^{2}$ Given that there are no grounds to dispose of the membership rights by waiving or abandoning it, a shareholder who would like to terminate its membership can only do so in three distinct ways: by disposing of its shares, when the company decides to redeem them, or upon the dissolution of the company. In the context of a corporate dispute, waiving membership in a company can be significantly hindered. Not only because the company may be reluctant to grant permission to dispose of its membership rights, which is often required by the articles of its association, but mainly because the demand for such rights is rather low. As it usually concerns the rights of a marginalized minority member, it can be expected that their emptor will find itself in exactly the same position.

The possibility of a shareholder leaving the company unilaterally, for significant reasons, is thus a value worth protecting. It is therefore difficult to accept a situation when a member, who finds itself in a difficult position that it is not culpable of, and it, in most cases, being a minority shareholder, while being unable to dispose of its share rights for legal or actual reasons, is being, at the same time, harmed by a majority shareholder, could not effect the termination of its membership in the company.

The legislator noticed this value in the amendment that introduces the simple joint-stock company to the K.s.h., protecting it with the legal action to resign as a shareholder of a company. Its purpose is to ensure the right of the grossly unjustly treated shareholder to exit from it, provided there is a just cause for that. According to the justification of the bill, it is to be an institution alternative to the dissolution of the company, allowing its further existence without the injured shareholder. Injury may occur in all

these cases, where the circumstances of the minority shareholder are not the sole causation for the circumstance giving rise to the court's decision. We may indicate the example of an economically unjustified, long-term accumulation of profit in a company, which is de facto decided by the majority shareholder, resulting in deprivation of the minority shareholder of the possibility of receiving dividend, especially if at the same time the company's profit is transferred to the majority shareholder in the consequence

2 Cf. A. Herbet, Obrót udziatami w spótce z o.o., Warszawa 2004, p. 15; P. Zdanikowski, Prawo udziałowe w spółce z o.o., Warszawa 2011, p. 62. 
of extra-corporate transactions, concluded by the company with the said majority shareholder. ${ }^{3}$

Therefore, the institution of shareholder's resignation seems to be the consequence of the postulate, as reported by science, "of the urgent requirement for statutory regulation of the right of a member of a limited liability company to leave the company for important reasons. This right should be implemented by means of a petition directed to a court" . $\mathrm{Al}$ though the postulate concerned a limited liability company, the similarity of the simple joint-stock company to a limited liability company suggests that the art. $300^{50}$ of the K.s.h. can also form its consummation.

This regulation also has a solid axiological justification. The idea of expanding the catalogue of measures protecting the interests of minority members, with the measure that does not reach as far in its consequences as to dissolve the entire company, and would at the same time be effective for the member in question, is thus justified. The optimization of law in this respect is expedient, to say the least.

\section{Existing solutions enabling unilateral "resignation" of a member from a company}

Polish law of commercial companies did not, to date, contain regulations that would allow for unilateral leaving of a member of a capital company for important reasons. Such instruments were absent for the jointstock company, and in the case of a limited liability company, this objective was accomplished, at least to some extent, by the action for dissolution of the limited liability company. This remedy may be brought to court by its member (or a member of its body) whenever achieving the company's objective has become impossible or for other important reasons, caused by the company's relations (art. 271 item 1 of the K.s.h.). De lege lata this

3 Justification of the draft act amending the act Code of Commercial Companies and some other acts, Sejm print No. 3236, p. 58, http:/ / orka.sejm.gov.pl/Druki8ka.nsf/ 0/5EA8D7DC70002162C12583A70034174A/\%24File/3236.pdf [access: 20.04.2021].

4 A. Radwan, Ius dissidentium. Granice konsensusu korporacyjnego i wtadzy większości w spótkach kapitałowych, Warszawa 2016, p. 616 and A. Pęczyk-Tofel, M.S. Tofel, "Wyjście” wspólnika lub akcjonariusza ze spótki kapitałowej, Przegląd Prawa Handlowego 2010, no. 7, pp. $46-48$. 
forms the sole possibility to "release" a member held in the company. ${ }^{5}$ Both the doctrine and the judicature assume, on the basis of an action for dissolution of the company, that the other important reasons caused by the company's relations boil down to situations where there is a permanent or repeated interference with the corporate position of a shareholder, in particular by depriving it of the membership rights by the company's management board or the majority shareholder and, consequently, further participation in the company becomes pointless, or economically unjustified for this member. ${ }^{6}$ However, the ineffectiveness of this remedy lies in the disproportionate effects it triggers. Its application can lead to the dissolution of a prosperous company, negatively affecting the rights of its stakeholders.

The subject literature also presents the position that a petition for resignation is also acceptable, de lege lata, pursuant to art. 271 item 1 of the K.s.h. This interpretation is supported by a maiori ad minus inference i.e. since it is possible to achieve the effect of the termination of the company's existence and, and therefore the resignation of all members, the more possible should it be for a single member thereof to resign. We observe additional support for this interpretation in the private law principle of the autonomy of the will of the parties and the consequent principle of the dissolution of ongoing legal relationships, which is quite contradictory to the actual status of "prisoner of the company". ${ }^{7}$ So far, however, this position was isolated. Nevertheless, even if we assume that the aforesaid interpretation of art. 271 item 1 of the K.s.h. is correct, it still proves difficult to imagine the practical application of this position in the judicature of common courts, without prior support of the Supreme Court for it. It must also be admitted that it raises numerous doubts related to the lack of positive regulation of important issues, both procedural (the issue of the capacity of being sued in the proceedings, or the scope of the judgment

5 For the concept of "prisoner of the company" c.f. A. Kappes, Uwolnienie "więźnia korporacyjnego" spótki z o.o. poprzez wypowiedzenie udziatu w spółce, Przegląd Prawa Handlowego 2015, no. 10, pp. 38-39.

6 A. Radwan, Ius dissidentium..., p. 66. In judicature, see Judgement of the Supreme Court of Poland of 22 April 1937, IC 1868/36, OSNC 1938, no. 4, item 163; Judgement of the Supreme Court of Poland of 10 April 2008, IV CSK 20/08; Judgement of the Supreme Court of Poland of 15 May 2009, II CSK 18/09; Judgement of the Supreme Court of Poland of 12 January 2018, II CSK 207/17.

7 A. Radwan, Ius dissidentium..., p. 68. 
adjudicating such a resignation) and material ones (responsibility for payment of the redemption price).

The right to "denunciate" articles of association could form a solution for unilateral resignation from a company. Neither the regulations on a limited liability company nor that on a joint-stock company provide for the possibility of denunciating the articles of association, as it is the case with a general partnership (art. $58 \S 1$ item 5 of the K.s.h.). As a rule, also the doctrine excludes that this right of a member of a company follows from the act. ${ }^{8}$ However, the doctrine (albeit this remains a contentious issue) also accepted that a limited liability company agreement can stipulate that one of the reasons for its dissolution may also be a declaration of its member. ${ }^{9}$. This solution (apart from its contentious nature) is also not effective, as the possibility of its application depends on the exact wording of the articles of association. It cannot, therefore, be treated as universal.

\section{The right to demand resignation from the company from a comparative perspective}

The German Act on limited liability company $(\mathrm{GmbHG})^{10}$ does not expressly provide for the right of a shareholder to resign from a limited liability company. However, whenever significant reasons (wichtige Gründe) are present, the doctrine and judicature adopt the existence of such a right. It takes the form of submitting a notice to leave a company (Kündigung) addressed to the company, which results, at the company's discretion, either in the redemption of share or their acquisition of by the company itself or a third party. If the company fails to redeem or acquire the share,

8 In the pre-war doctrine, however, a different position regarding a limited liability company was adopted by J. Tomkiewicz, J. Bloch, Spótki z ograniczona odpowiedzialnością. Kodeks handlowy. Art. 158-306 i 491-497. Komentarz wraz z uzasadnieniem Komisji Kodyfikacyjnej i orzecznictwem, Warszawa 1934, p. 204. In the latest literature (also in relation to a limited liability company), the position on the admissibility of termination of the company by a partner, for important reasons only, is presented by A. Kappes, Uwolnienie..., pp. 41-42.

9 The state of literature in this area is extensively described by A. Radwan, Ius dissidentium..., pp. 61-62, see especially footnotes: 101-104.

10 Gesetz betreffend die Gesellschaften mit beschränkter Haftung (GmbHG) vom 20.04.1892, RGBl. I, p. 477. 
then the shareholder is entitled to bring an action to dissolve the company, pursuant to $\S 61 \mathrm{GmbHG}^{11}$

Also, in Austrian law, despite its lack of explicit regulation in its company law, it is assumed that the resignation of a shareholder from a company, for significant reasons, is permissible. It is disputed, however, whether this should adopt the form of a member's declaration of exit from the company (Austritserklärung) or require action. ${ }^{12}$

Swiss law provides us with an interesting reference point for the institution of resignation from a simple joint-stock company. The regulation of the Swiss limited liability company provides not only for the right to exit from the company, but also a significantly modified demand for its dissolution, which may be taken into account by the court in that the court does not dissolve the company, but only adjudicates on the resignation of one of its members. Therefore, according to art. 821 section 1 of Obligationenrecht $t^{13}(\mathrm{OR})$, any of the shareholders may petition a court to dissolve the company for a significant reason. The court may then decide to apply another appropriate, optional solution. In particular, it may award the petitioning member remuneration corresponding to the real value of its shares. In turn, pursuant to art. 822 OR, a shareholder may, for significant reasons, request permission from the court to leave the company. The articles of association may make the right to resign from the company contingent on meeting certain conditions. The significant reasons, as referred to both in article 821 and in 822 of the OR, are understood in the same way in Swiss literature. Examples include continuous abuse of power and trust, no profit distribution, obfuscation of company data, continuous conflict of interest, repeated violations of the articles of association or resolutions of shareholders; ${ }^{14}$ or when significant premises of personal or material nature, due to which the articles of association were once concluded, no longer exist, so that

11 Cf. B. Grunewald, Gesellschaftsrecht, Tübingen 2008, p. 413, Nb 178; M. Lutter, P. Hommelhoff, GmbH-Gesetz Kommentar, Köln 2000, (§ 34), p. 502; O. Sosnitza, in: Kommenar zum Gesetz betreffend die Gesellschaften mit beschränkter Haftung (GmbH-Gesetz), vol. 1, ed. L. Michalski, München 2002, pp. 2021-2022.

12 Cf. M. Gelis, Kommentar zum GmbH-Gesetz, Wien 2009, p. 796.

13 Gesetz vom 18.12.1936, BBl. 1936, 605, 660.

14 Ch. Stäubli, in: Basler Kommentar. Obligationenrecht II. Art. 530-1186 OR, eds. H. Honsell, N.P. Vogt, R. Watter, Basel 2008, p. 1809. 
the achievement of the company's objective is no longer possible, significantly impeded or threatened. ${ }^{15}$

\section{Regulation of the right of a shareholder of a simple joint-stock company to resign}

\subsection{The systematics and content of regulation}

The institution of shareholder's resignation from a simple joint-stock company is comprehensively regulated by the art. $300^{50}$ of the K.s.h. This provision was included in Section 5 of Chapter 2, Section Ia of Title III of the K.s.h., entitled "Exclusion and resignation of a shareholder and annulment of shares". Within the systematics of the code, it is preceded by the regulation of an action to exclude a shareholder of a SJ-SC. This system is not, by any means, accidental. An action to exclude a shareholder (similar to an action to exclude a shareholder of a limited liability company) is, in fact, a structural reversal of the action for the resignation of a shareholder.

Article $300^{50}$ of the K.s.h. reads as follows:

At the petition of a shareholder, the court may order and adjudge its resignation from the company if there is a cause justified by the relations between the shareholders or between the company and the resigning shareholder, resulting in gross harm to the rights of the resigning shareholder (§ 1).

An action for the resignation of a shareholder from a company is brought against the company and all other shareholders to the court competent for the registered seat of the company (\$ 2).

Shares held by the resigning shareholder are subject to buyout at a price corresponding to their fair value, determined by the court as at the day of serving of the lawsuit. When deciding on the resignation of a shareholder, the court also specifies the date by which the buyout price should be paid to the resigning shareholder, along with interest due from the date of serving of the lawsuit $(\S 3)$.

15 M. Pfenninger, in: J.K. Kostkiewicz, P. Nobel, I. Schwander, S. Wolf, OR Schweizerisches Obligationenrecht, Zürich 2009, p. 1857. 
The shares held by the resigning shareholder are buyout on behalf of the other shareholders, in proportion to the number of shares they hold. The company and the shareholders against whom the action has been brought are jointly and severally liable for the payment of the buyout price $(\S 4)$.

\subsection{Prerequisites for the resignation of a shareholder}

The prerequisite for accepting the claim is a significant reason, justified by the relations between the shareholders or between the company and the resigning shareholder, resulting in its gross harm. This "significant reason" is a circumstance (situation) that occurred in the shareholder-company relationship or in relations between the shareholders. The provision does not differentiate whether, if that significant reason occurs between shareholders, it must also apply to the resigning shareholder, and whether it should affect all other shareholders, or whether it is sufficient for it to apply only to a part or even a single one of them. Thus, the legislator describes the "environment" of the emergence of a significant reason quite broadly. Just as broadly as it does in art. 271 item 1 of the K.s.h. using the phrase "a significant reason caused by the company's relations". It is difficult to see any semantic differences here, which raises the question of the purposefulness of use in art. $300^{50} \S 1$ of the K.s.h., of an expression that is different and more complex than the quoted one.

In practice, it seems that the most common "significant reason" will simply be the conflict between the shareholder requesting resignation and the majority shareholder (majority shareholders) and probably the underlying abuse of the latter's dominant position in the company. Here, at least part of the judicature developed on the basis of art. 271 item 1 of the K.s.h. will be applicable.

A "significant reason" as the premise for a decision on the resignation of a shareholder must result in harm to that member. Harm is the reverse of a privilege. It means treatment different from the model detrimental position; treating the shareholder worse than according to the optimal pattern. In addition, the harm must be flagrant. However, this concerns not the degree of its obviousness, i.e. that it is visible to anyone without a thorough assessment of the situation, but rather its quantitative and qualitative aspects. Therefore, it must relate to a breach of a substantial interest of the partner requesting resignation, and that breach may not 
be minor or trivial. It does not matter, however, whether the gross harm to a shareholder was intentional or not. The existence of this premise should be considered in the context of the rationale for the shareholder to continue to remain a member of the company, bearing in mind, however, that the principal way of terminating membership should be through the disposal of shares. Most often, therefore, this will concern the cases that in current literature are referred to as "imprisoning" a shareholder in the company.

\subsection{Legal capacity of parties to the proceedings}

The question of right of action does not raise any doubts. It is vested in the shareholder of a given company, claiming that there was a significant reason resulting in its gross harm. In the case of the capacity of being sued, this issue is a bit more complex. The wording of the provision leaves no doubt that irrespective of what relationship does the significant reason lay in, the company and all other shareholders should be sued. Since the case can only be pending against these persons, we are dealing with the mandatory joint participation of respondents (art. $72 \S 2$ of Polish code of civil procedure [hereinafter: K.p.c.]). In addition, it will also be uniform joint participation resulting from the substance of the disputed legal relationship (art. $73 \S 2$ K.p.c.). In a case of this kind, the court must issue a judgment of the same content for all of the participants. Therefore, it cannot admit actions against one uniform joint participant and dismiss actions against another, nor allow actions of varying degrees in respect of the individual participants. ${ }^{16}$

The framework of the capacity of being sued defined in this way can cause significant difficulties. And this is not about the practical inconvenience associated with the multitude of respondents, whether at the stage

16 Similarly, in literature and judicature, the participation of petitioners in a case regarding exclusion of a shareholder in a limited liability company is a qualified one, see B. Barut-Skupień, Wspótuczestnictwo procesowe w postępowaniu cywilnym i sądowo administracyjnym, Warszawa 2014 [database Legalis]; M. Jędrzejewska, K. Weitz, in: Kodeks postępowania cywilnego. Komentarz, vol. 1, part 1: Postępowanie rozpoznawcze, ed. T. Ereciński, Warszawa 2009, p. 264. See also the judgment of the Supreme Court of Poland of 19.3.1997, II CKN 31/97, OSNC 1997, no. 8, item 116, with the gloss of J. Kozak, OSP 1997, no. 11, item 208; Supreme Court decision of 28.2.1991, II CZ 277/90, Legalis. 
of preparing a lawsuit (gathering addresses of all other shareholders, preparing copies of lawsuits for them, etc.) or even at the stage of the course of proceedings (a justified absence of any of the respondents will result in the need to adjourn the hearing - see art. 214 K.p.c.). The crux lies in that the disposal of shares by the respondents during the trial will mean the collapse of their capacity of being sued and the need to sue the buyer instead (art. 195 K.p.c.). Since the subject of the proceeding are not the petitioner's shares, and even more so, the shares belonging to the respondents, the art. 192 item 3 of the K.p.c., which allows us to continue the proceedings despite the sale of the goods or rights subject to the dispute, will not apply. To mitigate this risk, petitioners will demand the claim to be secured by prohibiting the respondents from the sale of their shares. However, when the length of the proceedings is taken into account, this could mean freezing the share rights transactions in the respective company for up to several years. The new shareholders, who have acquired shares following a new issue after the action was already brought to court, would also be responding.

In contrast to the regulation of the K.s.h. regarding the exclusion of a shareholder, the art. $300^{50}$ of the K.s.h. does not give the possibility of any contractual modification of the circle of parties with the legal capacity to take part in the proceedings. A shareholder moving for resignation must therefore sue all other shareholders, regardless of whether they agree to its resignation or not. Other small shareholders may be among them. In the event there are also others who wish to initiate similar proceedings, it may happen that persons in a similar situation in different proceedings will adopt different procedural parties (once they will be acting as petitioners and in other proceedings as respondents).

\subsection{The scope of court jurisdiction in proceedings for the resignation of a shareholder and the evidence proceedings}

The scope of court jurisdiction in proceedings for the resignation of a shareholder is narrow. The court only decides on theresignation of the shareholder, sets the buyout price and the date of its payment together with due interest. It does not follow from the provision of art. $300^{50}$ of the K.s.h. that in a proceeding for the resignation of a shareholder, the court should order the company to buy out the shares and specify the date of such buyout. 
In connection with the above, the subject of evidentiary proceedings will be: a) determining whether there is a significant reason in the case, causing gross harm to the shareholder; $b$ ) determining the fair value of shares; c) determination of circumstances, affecting the setting of the date of payment of the buyout price. The burden of proof, according to the general principles, will rest with the petitioner (art. 6 of the Polish civil code [hereinafter: k.c.]).

\subsection{Judgment}

The main subject of the ruling in the case regarding the resignation of a shareholder of a simple joint-stock company is the judgment on its resignation. Semantics implies to adopt that this is how the relationship of the company is modified by eliminating the petitioner from its members. Nevertheless, a closer analysis of the provision in light of the rules determining the relationship between membership and participation rights requires a different conclusion to be adopted.

Membership in a company, as indicated above, results from ownership of shares. This means that it is the share right that implies membership, and not vice versa. Therefore, a judgment alone is not sufficient for the resignation to be effective, as its effectiveness requires the disposition of shares by the resigning shareholder. The same relationship is noticeable in the case of the exclusion of a shareholder in a limited liability company. Although the court decides to exclude it, the effects in this respect are only binding upon the takeover of the shares by the acquiring members, albeit with effect from the date of serving the lawsuit (art. 269 of the K.s.h.). This structure allows the judgment excluding the member to be treated as constitutive (such a judgment does not have to be effective at the time it becomes final, as its effects may also take place retroactively ${ }^{17}$ ). This is different in the event of the resignation of a shareholder. Cessation of the petitioner's membership takes place through the buyout of shares by the company, and the provision does stipulate that the redemption's effectiveness is an ex tunc one. Therefore, it should be recognized that the effects of the resignation of a shareholder occur at the time of the buyout, or more precisely: at the time of disposition of shares on general principles,

17 Cf. K. Piasecki, Wyrok pierwszej instancji w procesie cywilnym, Warszawa 1981, p. 147. 
which occurs only when this transaction is recorded in the register of shareholders (art. $300^{37} \S 1$ of the K.s.h.). Therefore, in contrast to the judgment excluding a shareholder of a limited liability company, which effects a new legal status retroactively, from the date of serving the lawsuit, on the date of payment (art. 269 of the K.s.h.), this condition is not created by a judgment adjudicating the resignation of a shareholder. A constitutive ruling is one which, like any other legal event, produces a law-forming effect in the form of a complete or partial change in the existing legal reality. ${ }^{18}$ In the event of the resignation of a shareholder, the judgment itself is only the basis for a buyout and, since it is not creating a new legal status, it is declarative. However, we must admit that some doubts in this respect are caused by art. $300^{50} \S 3$ of the K.s.h. as it mentions the right to claim interest due to the petitioner from the date of serving the lawsuit. This may indicate that the legislator's intention was, however, to create the law-making nature of adjudication of resignation. Certainly, this does not result from the content of this provision, especially when we compare it to the art. 269 of the K.s.h. ${ }^{19}$.

The Code does not indicate the premises for determining the date of payment of the buyout price. Since the payment of the buyout price is derivative to the buyout itself, the date of payment also indirectly determines the date of the buyout, in such a way that it should occur before the date of payment. The provision also does not specify the type of interest to be paid by the respondents. Therefore, it seems that it will concern statutory interest (art. $359 \S 2$ of the k.c.). The code also does not indicate whether there is a single date of payment of the buyout price for all shareholders who are obliged to buyout, or whether the court can personalize it. It seems that this differentiation may, e.g. stem from the striving to take the payment capacities of the shareholders into account. Such criteria are used, e.g. in division proceedings (division of inheritance, abolition of joint ownership, or division of joint property), where the court, when setting the repayment date, is guided by the time required for the party obliged to pay/ repay to collect the appropriate sum. With a large number of respondents,

18 K. Korzan, Orzeczenia konstytutywne w postępowaniu cywilnym, Warszawa 1972, p. 104; see also K. Piasecki, Wyrok..., p. 139.

19 This provision reads as follows: "A shareholder, for whom the acquired shares were paid on time, shall be deemed to be excluded from the company from the day of service of the lawsuit; however, this does not affect the validity of the activities in which it participated in the company after the day on which it was served the lawsuit". 
however, this can lead to excessive difficulties. In determining the date of payment of the buyout price (thus also indirectly that of the buyout itself), one should also bear in mind the consequences of the ruling in the context of securing the claim. If the petitioner has been granted security by prohibiting respondents from disposing of their shares, it is worth it to bring the entire buyout operation to an end before the collapse of the security, which - in accordance with art. 757 K.p.c. - occurs two months after the decision granting the claim has become final.

A judgment adjudicating the resignation of a shareholder is not an enforcement order. From the content of art. $300^{50}$ of the K.s.h. it does not follow that ordering a company to a buyout in a judgment would fall within the jurisdiction of the court. The buyout price that the respondents pay to the petitioner also falls outside this scope. Therefore, in this part, the judgment does not constitute an enforceable order.

\subsection{Redemption of shares and payment of the price}

After the judgment becomes final, the company should buy out the shares. It is therefore obliged to submit to the petitioner a declaration of intent concerning buyout. The provision does not specify any elements of this statement, similarly as in the case of taking over shares as part of an action to exclude a shareholder of a limited liability company. Therefore, it seems that the form of such a declaration should correspond to the form of disposal of shares, and thus it should be in at least a documented form, under pain of its nullity (art. $300^{36} \S 4$ of the K.s.h.). The submission of a buyout statement by the company to the petitioner does not yet have a disposing effect, as regards the transfer of shares, as this requires its recording in the register of shareholders (art. $300^{37} \S 1$ of the K.s.h.). The situation where the petitioner held shares granting different rights may thus become problematic. The Code also does not regulate this situation by requiring solely that the buyout should be proportional. Therefore, it seems that the company reserves the casting vote in this matter. The buyout statement should individualize shares by allocating shares with specific numbers to specific shareholders.

The final stage of the procedure is the payment of the buyout price and the distribution of its costs. Pursuant to art. $300^{50} \S 4$ sentence 2 of the K.s.h. the company and the shareholders against whom the petition has 
been brought are jointly and severally liable for the payment of the buyout price. This nature of liability for payment of the buyout price is, of course, advantageous for the petitioner. However, in the event of recourse claims, this means that the shareholders, who accepted the resignation, will bear the risk of insolvency of other shareholders (or the company itself). The shareholder whose assets are used to execute the claim may not be able to recover the appropriate portion of the claim from those shareholders who were insolvent. The company would not be liable in the event of recourse unless it held its own shares.

The above-described model of proceedings for the resignation of a shareholder assumes that following the judgment, the company will voluntarily buyout. However, it may also happen that the company does not submit a buyout statement. In such a case, a shareholder wishing to effectively resign should bring an action against the company requiring it to make a declaration of will (art. 64 of the k.c. in conjunction with art. 1047 K.p.c.). The obligation to make such a statement as a consequence of a decision to resign implicitly results from art. $300^{50} \S 3 \& 4$ of the K.s.h. as the company buys out on account of the remaining shareholders, and it is only the company that has the capacity of being sued in such a proceeding. Even when this proceeding is a straightforward one, it will require bearing both court and other organizational costs related to bringing a new action. Moreover, since we can assume that in many of the actions for resignation from the company, there is a corporate conflict at the root of the significant reasons resulting in gross harm, it should rather be assumed that companies will not be particularly willing to buy out. On the contrary, one should rather expect obstructive actions on their part.

The final judgment requiring the company to make a declaration of intent to buy out shares is not sufficient to produce the effects of the buyout. Since the sale of SJ-SC shares is of a real transaction, the buyout effects will only occur after they are recorded in the register of shareholders (art. $300^{37}$ $\S 1$ of the K.s.h.). ${ }^{20}$

The judgment ordering the company to make a declaration of intent to buyout shares does not constitute an enforceable order covering the payment of the buyout price. Therefore, for the resigning shareholder to be able to obtain the buyout price, provided that the company refuses to pay

20 More on this topic T. Sójka, Obrót akcjami prostej spótki akcyjnej, Przegląd Prawa Handlowego 2020, no. 1, pp. 5-11. 
voluntarily, it must bring another action against the company and/or other shareholders for payment of that price. This proceeding will also be uncomplicated from the point of view of the evidence, however, it will also require appropriate commitment.

\section{Conclusions and an attempt to optimize the regulation}

The institution of the resignation of a shareholder has sufficient axiological justification, and its regulation deserves our approval. However, our assessment of the provisions of art. $300^{50}$ of the K.s.h. remains negative.

Firstly, the adoption of mandatory and uniform participation by the responding party will trigger very serious difficulties in the implementation of the action. Albeit avoidable by means of securing order, it would, in turn, freeze the trading of shares for a longer period of time. The mandatory joint participation of the responding party is inessential from the point of view of the interests of both the shareholder requesting buyout and the remaining shareholders. This is an operation whose subject is membership, but only for the shareholder who petitions resignation. Given the scope of the jurisdiction of the court hearing the case, the participation of all other shareholders is superfluous. The court neither orders them to redeem the shares nor requires them to pay the price from them. Their rights would be thoroughly protected by the possibility of submitting an incidental intervention on the respondent's side. In the light of the fact that it is ultimately the company that buys out the shares in the name of all other shareholders, the possibility of suing only the company in the proceedings for the resignation of its shareholder seems to offer a more effective solution. The issue of the capacity of being sued in the proceedings for dissolution of a limited liability company is regulated in a similar fashion. Even if the judgment concerns the relationship of the company, and thus also the membership of all its members, they are not parties to this proceeding.

Secondly, the scope of court cognition in proceedings for the resignation of a shareholder is too narrow. The current shape of the institution of the resignation of a shareholder (apart from the issue of the capacity of being sued) can be effective only subject to the assumption that the company will buyout voluntarily. Meanwhile, there are no grounds to assume that the company will be cooperative in the resignation procedure. 
On the contrary, since the action for the resignation of a shareholder is grossly injuring the petitioner, one should rather expect that the entire case, from filing the claim to the effective payment, will be disputed. Therefore, we could expect a passive position of the company also after the judgment for the resignation of its shareholder. Thus, the judgment ruling only on the resignation of a shareholder, without ordering the company to buy out shares and establishing their price, will therefore mark only the beginning of the path leading to the effective leaving of the company for the petitioning party. In order to pursue it, the shareholder will have to bring another action to oblige the company to make a declaration of intent to buy out the shares, and only after completing this procedure will it be able to demand payment from the company and its other shareholders. Shall they fail to pay, another action has to be brought to court.

What may be proposed are three different paths for the optimization of the regulation of art. $300^{50}$ of the K.s.h. The first, which consists only in a slight modification of the current model, assumes only the resignation from the mandatory participation of the respondents, possibly together with the extended material validity of the judgment to other shareholders. This may not provide full optimization but will largely facilitate resignations. The second option also assumes reserving the capability of being sued for the company alone, however, it adopts a broader cognition of the court by specifying that the court also decides on the obligation to buyout, i.e. the judgment in this part would constitute an enforceable order. In such a case, the company's passivity following the judgment ordering buyout would justify the initiation of enforcement proceedings concerning the enforcement of non-pecuniary performances (art. 1050 K.p.c.). In such an arrangement, the shareholder seeking enforcement of payment of the buyout price would still have to file a separate action for payment against the company and/or other shareholders, however, its interest would be protected by the joint and several liabilities of other shareholders for the said buyout. The third option accepts the mandatory joint participation on the responding part, but at the same time assumes a different character of the judgment and a broader scope of court cognition. In order for the institution of shareholder's resignation to be effective, the judgment of resignation must be formative on one side, and on the other side, it should also constitute an enforcement title for the payment of buyout price. The task of the court should not rest solely in the declaration of 
resignation but also in the allocation of individual shares of the resigning shareholder to other shareholders and ordering them to pay the buyout price to the resigning shareholder. This would somewhat refer to a judgment abolishing joint ownership. It would be the court that would allocate the shares to the individual shareholders and award the appropriate amount for the price of these shares. Such a solution has both advantages and disadvantages. The primary advantage of this solution is that the matter of resignation of the shareholder would be settled in a single proceeding. Secondly, a decision granting shares would allocate the shares more flexibly. It could therefore balance the interests of the respondents in such a way that those who wish a proportional buyout of shares would not receive them, and those shareholders, who would wish to receive more than the result of the buyout would actually receive more. Thirdly, the lack of joint liability for payment of the buyout price spreads the risk of insolvency of some shareholders more equitably. In such an arrangement, there is no recourse after the performance of the service by one of the joint and several debtors. The risk of lack of payment resulting from the insolvency of one of the respondents would, therefore, be borne by the petitioner and not by the remaining shareholders. The disadvantage of this solution, however, is the requirement to sue all the shareholders.

It seems that the most optimal solution is the option indicated above as the second one. On the one hand, it only involves the company and the shareholder requesting resignation in the resignation process, and on the other hand, it assumes that the decision on the basis of which the shareholder resigns also constitutes an enforceable title in the matter of ordering the buyout by the company.

\section{Bibliography}

Barut-Skupień B., Wspótuczestnictwo procesowe w postępowaniu cywilnym i sq̨owo administracyjnym, Warszawa 2014.

Basler Kommentar. Obligationenrecht II. Art. 530-1186 OR, eds. H. Honsell, N.P. Vogt

N.P., R. Watter, Basel 2008.

Gelis M., Kommentar zum GmbH-Gesetz, Wien 2009.

Grunewald B., Gesellschaftsrecht, Tübingen 2008.

Herbet A., Obrót udziałami w spótce z o.o., Warszawa 2004. 
Kappes A., Uwolnienie "więźnia korporacyjnego" spótki z o.o. poprzez wypowiedzenie udziału w spótce, Przegląd Prawa Handlowego 2015, no. 10.

Kodeks postępowania cywilnego. Komentarz., vol. 1, part 1: Postępowanie rozpoznawcze, ed. T. Ereciński, Warszawa 2009.

Kommentar zum Gesetz betreffend die Gesellschaften mit beschränkter Haftung (GmbH-Gesetz), vol. 1, ed. L. Michalski, München 2002.

Korzan K., Orzeczenia konstytutywne w postępowaniu cywilnym, Warszawa 1972.

Kostkiewicz J.K., Nobel P., Schwander I., Wolf S., OR Schweizerisches Obligationenrecht, Zürich 2009.

Lutter M., Hommelhoff P., GmbH-Gesetz Kommentar, Köln 2000.

Pęczyk-Tofel A., Tofel M.S., "Wyjście” wspólnika lub akcjonariusza ze spótki kapitatowej, Przegląd Prawa Handlowego 2010, no. 7.

Piasecki K., Wyrok pierwszej instancji w procesie cywilnym, Warszawa 1981.

Radwan A., Ius dissidentium. Granice konsensusu korporacyjnego i władzy większości w spótkach kapitałowych, Warszawa 2016.

Sójka T., Obrót akcjami prostej spótki akcyjnej, Przegląd Prawa Handlowego 2020, no. 1.

Tomkiewicz J., Bloch J., Spótki z ograniczonq odpowiedzialnością. Kodeks handlowy. Art. 158-306 i 491-497. Komentarz wraz z uzasadnieniem Komisji Kodyfikacyjnej i orzecznictwem, Warszawa 1934.

Wach-Pawliczak M., Wyłączenie wspólnika ze spótki z ograniczoną odpowiedzialnościa, Warszawa 2016.

Zdanikowski P., Prawo udziałowe w spótce z o.o., Warszawa 2011.

\section{Sum mary}

The subject matter of the article is the analysis of the institution of the resignation of a shareholder in a simple joint-stock company. The author considers the introduction of an institution granting a shareholder the right to exit the company as justified. It may form an instrument for the protection of interests of shareholder (usually the minority of them), which on the one hand are marginalized by other shareholders (usually the majority), and on the other hand find it impossible (due to legal or actual grounds) to dispose of their shares, regardless of whether the company does not consent it, or there is no demand for them, due to the situation of the company. The author critically assesses the regulation of the institution of resignation. He believes that it will be ineffective in its current form: first, because of the requirement for the petitioner to sue all the remaining shareholders. Secondly, due to the scope of court cognition, which is too narrow, the current regulation can be effective only if the company voluntarily buys out after losing the case in the resignation proceedings. Otherwise, effective resignation from 
the company will require an action for a commitment to make a declaration of intent, followed by an action for payment. The article also contains specific suggestions for optimizing this provision.

Key words: simple joint-stock company, resignation of a shareholder, membership in a simple joint-stock company

\section{USTĄPIENIE AKCJONARIUSZA Z PROSTEJ SPÓŁKI AKCYJNEJ \\ Streszczenie}

Przedmiotem artykułu jest analiza instytucji ustąpienia akcjonariusza z prostej spółki akcyjnej. Autor uznaje wprowadzenie instytucji przyznającej akcjonariuszowi prawo wyjścia ze spółki za uzasadnione. Może być to bowiem instrument ochrony interesów akcjonariusza (najczęściej mniejszościowego), który z jednej strony jest marginalizowany przez pozostałych akcjonariuszy (najczęściej większościowych), z drugiej zaś strony nie ma możliwości (prawnych lub faktycznych) zbycia swoich akcji, czy to dlatego, że spółka nie zgadza się na to czy to z tego powodu, z uwagi na sytuację w spółce, nie ma na nie popytu. Autor krytycznie jednak ocenia sposób uregulowania instytucji ustąpienia. Uważa, że w obecnym kształcie będzie ona nieefektywna: po pierwsze, z uwagi na wymóg, by powód pozwał wszystkich pozostałych akcjonariuszy. Po drugie, ze względu na zakres kognicji sądu, który jest za wąski. Obecna regulacja może być efektywna jedynie wówczas, gdy spółka dobrowolnie dokona wykupu po przegraniu procesu o ustąpienie. W przeciwnym razie efektywne ustąpienie ze spółki będzie wymagało wytoczenia powództwa o zobowiązanie do złożenia oświadczenia woli, a następnie powództwa o zapłatę. Artykuł zawiera także konkretne propozycje optymalizacji tego przepisu.

Słowa kluczowe: prosta spółka akcyjna, ustąpienie akcjonariusza z prostej spółki akcyjnej, członkostwo w prostej spółce akcyjnej

\section{ВЫХОД АКЦИОНЕРА ИЗ ПРОСТОГО АКЦИОНЕРНОГО ОБЩЕСТВА}

\section{Резгме}

Предметом статьи является анализ института выхода акционера из простого акционерного общества. Автор считает обоснованным введение института, предоставляющего акционеру право выхода из общества. Это может быть инструмент защиты интересов акционера (чаще всего миноритарного 
акционера), который, с одной стороны, маргинализирован другими акционерами (чаще всего мажоритарными акционерами), а с другой стороны, не имеет возможности (юридически или фактически) продать свои акции, либо потому, что компания не согласна с его решением, либо по той причине, что в связи с ситуацией в компании на них нет спроса. Однако автор критически оценивает способ регулирования институтов выхода акционера. Он считает, что в нынешнем виде он будет неэффективным: во-первых, изза требования, чтобы истец подал иск в суд на всех остальных акционеров. Во-вторых, из-за слишком узкой юрисдикции суда. Текущее регулирование может быть эффективным только в том случае, если компания добровольно выкупит акции после того, как проиграет процесс увольнения. В противном случае для фактического выхода из компании потребуется предъявление иска об обязательстве подать заявление о волеизъявлении, а затем иск о выплате. В статье содержатся также конкретные предложения по оптимизации этого закона.

Ключевые слова: простое акционерное общество, выход акционера из простого акционерного общества, членство в простом акционерном обществе 